(c) American Dairy Science Association, 2004.

\title{
Effects of Dry Cow Grouping Strategy and Prepartum Body Condition Score on Performance and Health of Transition Dairy Cows
}

\author{
L. L. Contreras, ${ }^{\star}$ C. M. Ryan, and T. R. Overton \\ Department of Animal Science \\ Cornell University, Ithaca, NY 14853
}

\begin{abstract}
Multiparous Holstein cows $(\mathrm{n}=337)$ on two commercial dairy farms were used to determine the effects of feeding a close-up diet for 21 (treatment S) or $60 \mathrm{~d}$ (treatment L). Milk yield was not affected by treatment; however, cows fed treatment $\mathrm{S}$ tended to have increased yields of fat, $3.5 \%$ fat-corrected milk, and protein during the first 5 mo of their subsequent lactation compared to treatment $\mathrm{L}$. Cows fed treatment $\mathrm{L}$ gained more body condition score (BCS) during the dry period and had longer days to first service. As a secondary objective, relationships of BCS at dry off and subsequent performance were evaluated. Cows with initial BCS $\leq 3.0$ (thinner) tended to produce more milk during early lactation than cows with initial $\mathrm{BCS} \geq 3.25$ (fatter). A trend for an interaction of treatment and initial BCS existed for milk yield such that thinner cows fed treatment S produced the most milk and fatter cows fed treatment $\mathrm{S}$ produced the least amount of milk; cows fed treatment L regardless of BCS produced an intermediate amount of milk. Subsequent reproductive performance was similar among thinner and fatter cows. These data indicate that 2 group nutritional strategies for dry cows are preferred, and BCS at dry off should be considered when determining grouping and nutritional strategies for dry cows. Furthermore, moderately thin cows at dry off do not have impaired performance during their subsequent lactation compared to cows of greater BCS.
\end{abstract}

(Key words: periparturient cow, grouping, body condition score)

\section{INTRODUCTION}

Transition cow biology and management has become a focal point for research in nutrition and physiology during the past $15 \mathrm{yr}$ (Bell, 1995; Grummer, 1995; Drackley, 1999; Overton et al., 2000). Several forces

Received April 10, 2003.

Accepted September 8, 2003.

Corresponding author: T. R. Overton; e-mail: tro2@cornell.edu.

*Current address: 1423 Breezeway Ct., Merced, CA 95340. have underpinned the evolution of this research. First, it was recognized that metabolic disorders afflicting cows during the periparturient period are interrelated in their occurrence (Curtis et al., 1985), and approximately $50 \%$ of cows have one or more adverse health events during this period (Ferguson, 2001). Furthermore, approximately $25 \%$ of cows that leave dairy herds leave during the first 60 DIM, with an uncertain additional percentage of animals leaving dairy herds after 60 DIM because of downstream effects of periparturient difficulty (Godden et al., 2002).

The concept of feeding additional concentrate to dairy cows during the dry period is not new (Woodward et al., 1932; Campbell and Flux, 1948; Lees et al., 1948; Schmidt and Schultz, 1959), and research conducted more recently (Minor et al., 1998; Dann et al., 1999; VandeHaar et al., 1999) generally is supportive of this strategy. Thus, feeding diets higher in energy and protein to dairy cows during the late dry period has resulted in the evolution of 2-group nutritional management strategies for dry cows. This "state of the art" feeding strategy results in a "close-up" diet fed during the last 3 wk of the dry period that contains more energy and protein than the diet fed during the early dry period.

As mentioned above, the close-up diet is fed on many farms for the last 3 wk prior to calving; however, until recently few data were available to support this choice of duration. Two experiments have been published recently that provide insight on this topic. Robinson et al. (2001) fed cows and first-calf heifers either a control close-up diet or a close-up diet supplemented with additional energy and protein for varied time periods on commercial dairy farms in the western US. They determined that there was a significant increase in milk yield over a full lactation when heifers and cows were fed these diets for $15 \mathrm{~d}$ compared with $5 \mathrm{~d}$. Additional supplementation of energy and protein to the diet yielded more milk during the full lactation only when it was fed for $15 \mathrm{~d}$ prepartum.

In an experiment reported recently (Corbett, 2002), lactational milk yield and incidence of metabolic disorders were examined relative to days in the close-up group for over 13,000 cows on five dairy farms in the 
Table 1. Characterization of prepartum nutrition programs on the 2 cooperating farms.

\begin{tabular}{|c|c|c|c|c|}
\hline \multirow[b]{2}{*}{ Item } & \multicolumn{2}{|c|}{ Farm 1} & \multicolumn{2}{|c|}{ Farm 2} \\
\hline & Far-off & Close-up & Far-off & Close-up \\
\hline DMI formulated, ${ }^{1} \mathrm{~kg} / \mathrm{d}$ & 14.1 & 12.7 & 11.4 & 9.8 \\
\hline $\mathrm{NE}_{\mathrm{L}}, \mathrm{Mcal} / \mathrm{kg} \mathrm{DM}$ & 1.40 & 1.61 & 1.41 & 1.49 \\
\hline $\mathrm{CP}, \% \mathrm{DM}$ & 12.8 & 15.9 & 15.4 & 16.3 \\
\hline Total required $\mathrm{MP}^{2} \mathrm{~g} / \mathrm{d}$ & 922 & 1104 & 829 & 1072 \\
\hline Total supplied MP, ${ }^{2} \mathrm{~g} / \mathrm{d}$ & 1189 & 1418 & 904 & 924 \\
\hline $\mathrm{NDF}, \% \mathrm{DM}$ & 47.5 & 40.4 & 45.8 & 42.2 \\
\hline peNDF, ${ }^{3} \% \mathrm{DM}$ & 40 & 30 & 37 & 33 \\
\hline $\mathrm{NFC}, \% \mathrm{DM}$ & 33 & 34 & 32 & 34 \\
\hline $\mathrm{Ca}, \% \mathrm{DM}$ & 0.70 & 0.71 & 0.55 & 0.50 \\
\hline $\mathrm{P}, \% \mathrm{DM}$ & 0.50 & 0.49 & 0.25 & 0.27 \\
\hline $\mathrm{Mg}, \% \mathrm{DM}$ & 0.38 & 0.40 & 0.24 & 0.32 \\
\hline $\mathrm{K}, \% \mathrm{DM}$ & 1.63 & 1.04 & 1.58 & 1.47 \\
\hline DCAD & $\ldots$ & +9 & $\ldots$ & +27 \\
\hline
\end{tabular}

${ }^{1}$ Calculated based upon formulated diets from herd nutritionist.

${ }^{2}$ Calculated using CNCPS 4.0 (Fox et al., 1992) based upon formulated DMI.

${ }^{3}$ Physically effective NDF calculated from CNCPS library values.

western United States. Cows in the close-up group for approximately $21 \mathrm{~d}$ produced $1200 \mathrm{~kg}$ more milk for the lactation compared with those in the close-up group less than $7 \mathrm{~d}$. This increased production likely was partly the result of decreased occurrence of metabolic disorders in cows fed a close-up diet for approximately $21 \mathrm{~d}$ compared with less than $7 \mathrm{~d}$.

These experiments did not explore feeding the closeup diet for longer than the 21-d period currently recommended by most advisors on transition cow management. To date, only one experiment has addressed this issue. Mashek and Beede (2001) fed cows on 2 commercial dairy farms a standard close-up diet for an average of either 18 or $37 \mathrm{~d}$ prepartum. There was a slight improvement in energy status of cows fed the close-up diet for $37 \mathrm{~d}$ prepartum; however, differences in milk production during early lactation were not significant. Health effects were farm-specific - one farm had an increased incidence of retained placenta when cows were fed the close-up diet for an average of $37 \mathrm{~d}$ prepartum.

Feeding the close-up diet for the entire dry period could be advantageous from both nutritional and grouping perspectives; however, it would increase feed cost on most commercial farms. For a variety of reasons (herd size, labor considerations, etc.), one-group nutritional strategies would be more practically implemented on many commercial dairy farms; however, the effects of feeding the close-up diet for the entire dry period on subsequent lactational performance and health are not known. The objective of our experiment was to determine whether feeding the close-up diet for the entire dry period would result in subsequently improved productive performance, health, and reproduction compared with the 2-group nutritional management system for dry cows. A second objective was to assess BCS dynamics in relation to subsequent lactational performance, health, and reproductive performance.

\section{MATERIALS AND METHODS}

\section{Cows and Treatments}

Cows ( $\mathrm{n}=337)$ entering second or greater lactation on 2 commercial dairy farms were randomly assigned $60 \mathrm{~d}$ prior to their expected calving dates to 1 of 2 treatments. Cows assigned to treatment $\mathrm{L}$ were fed a close-up (high energy) diet (Table 1) for a mean of 62 $\pm 17 \mathrm{~d}$ (SD) prior to parturition (farm 1 mean $=63 \pm$ $17 \mathrm{~d}$; farm 2 mean $=60 \pm 10 \mathrm{~d}$ ). Cows assigned to treatment $\mathrm{S}$ were fed a conventional far-off diet (Table 1) beginning at dry off a mean of $41 \pm 13 \mathrm{~d}$ (farm 1 mean $=42 \pm 14 \mathrm{~d}$, farm 2 mean $=40 \pm 11 \mathrm{~d}$ ). On d 21 prior to expected parturition ( $21 \pm 6 \mathrm{~d}$ ), cows assigned to treatment $\mathrm{S}$ were moved into the same group as cows assigned to treatment $\mathrm{L}$ and fed the close-up diet. On both farms, cows that were dried off more than $60 \mathrm{~d}$ prior to expected calving date were assigned to treatment $\mathrm{S}$. On farm $1, \mathrm{~L}=108$ and $\mathrm{S}=114$ cows and on farm $2, \mathrm{~L}=53$ and $\mathrm{S}=62$ cows. There were 119 and 64 second lactation, 52 and 28 third lactation, and 51 and 23 fourth or greater lactation cows included on farms 1 and 2, respectively. The first cows assigned to the experiment calved in November 2000, and the last cows calved in July 2001. Although cows were housed in groups, the experimental treatments consisted of grouping strategies, and cows assigned to both treatments were commingled without overcrowding during the last $21 \mathrm{~d}$ prior to expected calving and represented cows at a variety of days relative to calving at any one 
Table 2. Characterization of postpartum nutrition programs on the 2 cooperating farms.

\begin{tabular}{|c|c|c|c|}
\hline \multirow[b]{2}{*}{ Item } & \multicolumn{2}{|c|}{ Farm 1} & \multirow{2}{*}{$\frac{\text { Farm } 2}{\text { High }}$} \\
\hline & Fresh & High & \\
\hline DMI formulated, ${ }^{1} \mathrm{~kg} / \mathrm{d}$ & 19.0 & 23.4 & 20.2 \\
\hline $\mathrm{NE}_{\mathrm{L}}, \mathrm{Mcal} / \mathrm{kg} \mathrm{DM}$ & 1.68 & 1.71 & 1.80 \\
\hline $\mathrm{CP}, \% \mathrm{DM}$ & 17.2 & 18.3 & 18.9 \\
\hline Total required $\mathrm{MP},{ }^{2} \mathrm{~g} / \mathrm{d}$ & 2309 & 2790 & 2735 \\
\hline Total supplied MP, ${ }^{2} \mathrm{~g} / \mathrm{d}$ & 2152 & 2769 & 2469 \\
\hline NDF, \% DM & 34.6 & 31.8 & 28.8 \\
\hline peNDF, ${ }^{3} \% \mathrm{DM}$ & 24 & 20 & 21 \\
\hline $\mathrm{NFC}, \% \mathrm{DM}$ & 39 & 42 & 42 \\
\hline $\mathrm{Ca}, \% \mathrm{DM}$ & 0.91 & 0.88 & 1.01 \\
\hline $\mathrm{P}, \% \mathrm{DM}$ & 0.46 & 0.45 & 0.38 \\
\hline $\mathrm{Mg}, \% \mathrm{DM}$ & 0.35 & 0.35 & 0.31 \\
\hline $\mathrm{K}, \% \mathrm{DM}$ & 1.35 & 1.36 & 1.26 \\
\hline
\end{tabular}

${ }^{1}$ Calculated based upon formulated diets from herd nutritionist.

${ }^{2}$ Calculated using CNCPS 4.0 (Fox et al., 1992) based upon formulated DMI.

${ }^{3}$ Physically effective NDF calculated from CNCPS feed library values.

time for both treatments; thus, in this experiment the individual cow was considered to be the experimental unit. The lack of significant farm $\times$ treatment interactions for any response variable measured suggests that the responses to treatment were largely independent of differences of experimental site.

After calving, cows were housed together and fed the same diets (Table 2). On farm 1, cows spent the first 3 $d$ in the hospital pen, followed by the fresh pen for 30 to $50 \mathrm{~d}$ and the high pen for the remainder of the experiment. On farm 2 , cows spent the first $3 \mathrm{~d}$ in the hospital pen, followed by the high pen for the remainder of the experiment. All cows were administered the sustained release form of bST (Posilac, Monsanto Inc., St. Louis, MO) at 2-wk intervals beginning during wk 9 of lactation.

\section{Sample Collection and Analysis}

The herd nutritionist formulated diets as forage analysis and forage type changed in order to maintain consistent nutrient composition of individual diets. Ingredient and nutrient characterization of the diets (Tables 1 and 2) reflect weighted composites from throughout the experimental period. Milk yield and composition (fat and true protein) were measured on each farm during the monthly test-day visit by DairyOne Laboratories (Ithaca, NY). Two evaluators assigned BCS (5point scale where $1=$ thin and $5=$ fat; Wildman et al., 1982 ) to individual cows on a monthly basis for at least 2 mo prepartum and 3 mo postpartum.

Blood samples were collected from a random sample of cows receiving each treatment diet. Samples were obtained by venipuncture of the coccygeal vein or artery into evacuated test tubes containing sodium heparin (Vacutainer; Becton Dickson, Rutherford, NJ) on $1 \mathrm{~d}$ during $d 5$ to 12 prepartum $(n=24$ for $S$ and $n=23$ for $\mathrm{L})$ and on $1 \mathrm{~d}$ during $\mathrm{d} 5$ to 15 postpartum $(\mathrm{n}=37$ for $\mathrm{S}$ and $\mathrm{n}=50$ for $\mathrm{L}$ ). Blood samples were collected approximately 3 to $5 \mathrm{~h}$ after feeding on both farms. Care was taken to minimally disturb animals during blood collection. Samples were centrifuged $(1380 \times g$ for $15 \mathrm{~min}$ ), and plasma was transferred to microcentrifuge tubes and placed in ice for transport to the laboratory. Upon arrival at the laboratory, samples were frozen at $-20^{\circ} \mathrm{C}$ until subsequent analysis of prepartum samples for NEFA (NEFA-C kit, Wako Chemicals USA, Dallas, TX) as modified by McCutcheon and Bauman (1986). Samples collected during the postpartum period were analyzed for BHBA (BHBA dehydrogenase; kit \#310A; Sigma Diagnostics Inc., St. Louis, MO).

Herdspersons were responsible for recording all incidences of metabolic and nonmetabolic disorders throughout the experiment. The information was then retrieved via a computerized record keeping system (DairyComp 305; Valley Agricultural Software, Tulare, CA) and hand-written treatment records (DairyWorks Management System, Cow Health Record, Tempe, AZ). Metabolic disorders recorded included retained placenta, ketosis, milk fever, metritis, and displaced abomasum. Nonmetabolic disorders were indigestion, mastitis, and pneumonia. Events of each disorder were recorded only if they warranted treatment.

\section{Statistical Analysis}

As indicated above, treatments were applied to individual cows and cows assigned to the 2 treatments were commingled during the last $21 \mathrm{~d}$ before expected parturition. Differences in pens were minimized, and it was assumed that any unintended effects of pen would be negligible; therefore, the cow was considered to be the experimental unit. Data were analyzed as a completely randomized design with repeated measurements using the PROC MIXED procedure of SAS (2001). The model used to analyze milk yield and composition data included the terms farm, treatment, block (initial BCS of either $\geq 3.25$ or $\leq 3.0$ ), test day, the 2 -way interactions of farm with treatment and block, and treatment with block and test day, and the 3-way interactions of farm, treatment, and test day and farm, treatment, and block. Days in milk at test day was used as a covariable for milk yield and composition. The model used to analyze BCS data included the effects used for milk with an additional 3-way interaction of block, treatment, and test day. The model used to analyze the blood metabolite data included the effects of farm, treatment, and the interaction of farm and treatment. The model used 
Table 3. Effects of feeding the close-up diet for the last 3 wk prior to calving (treatment $\mathrm{S}$ ) or for the entire dry period (treatment $\mathrm{L}$ ) on milk yield and composition during the first 5 monthly test days.

\begin{tabular}{|c|c|c|c|c|}
\hline \multirow[b]{2}{*}{ Item } & \multicolumn{2}{|c|}{ Treatment } & \multirow[b]{2}{*}{ SEM } & \multirow[b]{2}{*}{$P$} \\
\hline & $\mathrm{S}$ & $\mathrm{L}$ & & \\
\hline Milk, kg/d & 42.3 & 41.9 & 0.83 & 0.76 \\
\hline Fat, \% & 3.67 & 3.56 & 0.04 & 0.07 \\
\hline Fat, kg/d & 1.55 & 1.48 & 0.03 & 0.13 \\
\hline $3.5 \% \mathrm{FCM}, \mathrm{kg} / \mathrm{d}$ & 43.5 & 41.8 & 0.85 & 0.13 \\
\hline True protein, $\%$ & 2.83 & 2.77 & 0.02 & 0.05 \\
\hline True protein, kg/d & 1.20 & 1.15 & 0.02 & 0.15 \\
\hline
\end{tabular}

to analyze the reproductive data included the effects of farm, block, treatment, and 2- and 3-way interactions of these effects. Health disorder data were analyzed using the GENMOD procedure of SAS (2001). Statistical significance was declared at $P<0.05$, and trends towards significance at $0.05<P<0.15$. Least squares means are presented throughout.

\section{RESULTS AND DISCUSSION}

Milk yield and composition during the first 5 monthly test days as affected by prepartum grouping strategy are presented in Table 3. Milk yield was not affected significantly by treatment; however, cows assigned to treatment $\mathrm{L}$ tended $(P<0.07)$ to produce milk with a lower fat content and a significantly $(P<0.05)$ lower true protein content. This led to trends $(P<0.15)$ for decreased yields of fat, $3.5 \% \mathrm{FCM}$, and true protein compared with cows assigned to treatment S. A treatment by time interaction occurred $(P<0.01)$ for BCS (Figure 1) such that BCS increased slightly more during the dry period for cows assigned to treatment L compared with those assigned to treatment $\mathrm{S}$; however, BCS of cows assigned to the 2 prepartum treatments

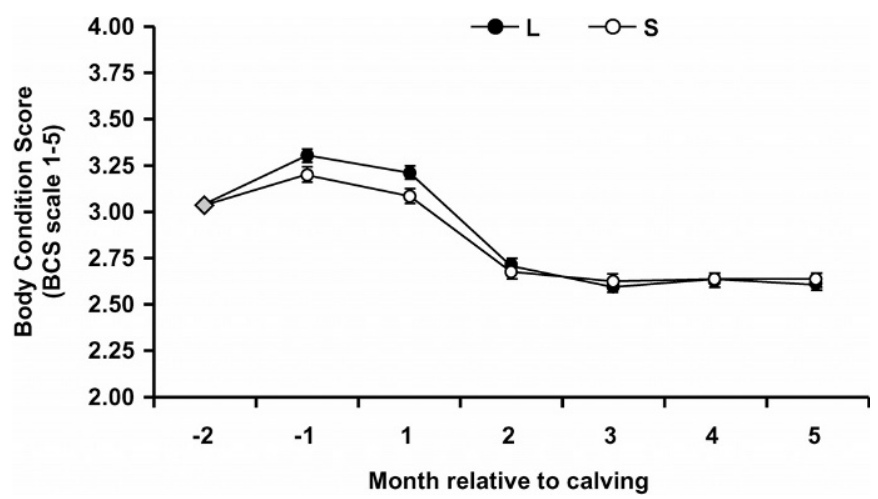

Figure 1. Effects of feeding the close-up diet for the last $3 \mathrm{wk}$ prior to calving (treatment $\mathrm{S}$ ) or for the entire dry period (treatment 1) on body condition score during the dry period and first 5 mo of lactation (treatment $\times$ test, $P<0.01$ ).
Table 4. Effects of feeding the close-up diet for the last $3 \mathrm{wk}$ prior to calving (treatment $\mathrm{S}$ ) or for the entire dry period (treatment $\mathrm{L}$ ) on incidence of metabolic and nonmetabolic health disorders.

\begin{tabular}{lrr}
\hline & \multicolumn{2}{c}{ Treatment } \\
\cline { 2 - 3 } Item & $\mathrm{S}(\mathrm{n}=171)$ & $\mathrm{L}(\mathrm{n}=177)$ \\
\hline Ketosis & $1.2 \%(2)$ & $4.0 \%(7)$ \\
Metritis & $0.6 \%(1)$ & $1.7 \%(3)$ \\
Retained fetal membranes & $12.9 \%(22)$ & $14.7 \%(26)$ \\
Displaced abomasum & $0.6 \%(1)$ & $5.6 \%(10)$ \\
Milk fever & $3.5 \%(6)$ & $5.1 \%(9)$ \\
Mastitis & $5.8 \%(10)$ & $6.8 \%(12)$ \\
Pneumonia & $1.8 \%(3)$ & $4.0 \%(7)$ \\
\hline
\end{tabular}

were similar during months 2 through 5 of lactation. These data for BCS are similar to those reported by Mashek and Beede (2001) for cows fed the close-up diet for a longer period of time; however, they reported farmspecific negative effects on milk yield and composition of feeding the close-up diet for a longer period of time. Contrary to the farm-specific effect reported by Mashek and Beede (2001), the interaction of farm and treatment was not significant for variables measured in our experiment. In their experiment, cows were fed treatment diets for fewer days than this experiment, which may have contributed to inconsistent effects.

The number of cases and incidence of metabolic and nonmetabolic health disorders are presented in Table 4. The incidence of most health disorders was similar across the 2 treatment groups; however, cows assigned to treatment $\mathrm{L}$ had increased $(P<0.05)$ incidence of displaced abomasum. Supporting the minimal effects of treatment on occurrence of most health disorders, prepartum concentrations of plasma NEFA and postpartum concentrations of plasma BHBA were not affected by treatment (Table 5). Likewise, in previous studies there was no effect of treatment on plasma concentrations of BHBA (Mashek and Beede, 2001).

Reproductive parameters for cows confirmed pregnant by 250 DIM for cows assigned to the 2 prepartum

Table 5. Effects of feeding the close-up diet for the last 3 wk prior to calving (treatment $\mathrm{S}$ ) or for the entire dry period (treatment $\mathrm{L}$ ) on plasma NEFA during d 5 to 12 prepartum and plasma BHBA during d 5 to 15 postpartum.

\begin{tabular}{|c|c|c|c|c|c|c|}
\hline \multirow[b]{2}{*}{ Item } & \multicolumn{2}{|c|}{ Treatment } & \multirow[b]{2}{*}{ SEM } & \multicolumn{3}{|c|}{$P$} \\
\hline & $\mathrm{S}$ & $\mathrm{L}$ & & Trt & farm & $\operatorname{Trt} \times$ farm \\
\hline \multicolumn{7}{|c|}{ NEFA, $\mu \mathrm{Eq} / \mathrm{L}$} \\
\hline Farm 1 & 99 & 107 & 31 & 0.39 & 0.01 & 0.56 \\
\hline Farm 2 & 159 & 200 & 25 & & & \\
\hline \multicolumn{7}{|c|}{ BHBA, mg/dL } \\
\hline Farm 1 & 9.4 & 11.9 & 2.1 & 0.42 & 0.65 & 0.59 \\
\hline Farm 2 & 1 & 11.7 & 1.4 & & & \\
\hline
\end{tabular}


Table 6. Effects of feeding the close-up diet for the last 3 wk prior to calving (treatment $\mathrm{S}$ ) or for the entire dry period (treatment L) on subsequent reproductive performance through 250 DIM.

\begin{tabular}{lcclll}
\hline & \multicolumn{2}{c}{ Treatment } & & \\
\cline { 2 - 3 } Item & $\mathrm{S}$ & $\mathrm{L}$ & $\mathrm{SEM}$ & $P$ \\
\hline Days to first service & 63.8 & 69.2 & 1.7 & 0.01 \\
Days open & 117 & 104 & 8 & 0.19 \\
Services/conception & 2.2 & 2.2 & 0.2 & 0.83 \\
Cows not pregnant $^{1}$ & $40 / 161$ & $36 / 159$ & & \\
\hline
\end{tabular}

${ }^{1}$ Represents cows that left herd or were otherwise not pregnant by 250 DIM.

treatments are presented in Table 6. Cows assigned to treatment $\mathrm{L}$ had significantly $(P<0.01)$ longer days to first service; however, services per conception and the proportion of cows not pregnant by 250 DIM were similar across the 2 treatments.

Although performance and health of cows fed the close-up diet for the entire dry period on these farms was not impaired dramatically, feeding the close-up diet for the entire dry period did not result in improved performance in any of the measured variables. Given the additional cost of feeding a close-up diet for a longer period of time, economics favor the 2-group nutritional management system for dry cows.

The impact of prepartum BCS on subsequent lactational and reproductive performance and health was evaluated. Current industry recommendations are for cows to achieve a BCS of 3.25 to 3.50 at dry off, and neither gain nor lose BCS during the dry period. Body condition score dynamics and its effects on subsequent performance and health have not been evaluated within the context of modern transition cow nutritional management systems.

Cow data were divided into 2 groups based upon BCS at dry off $(\leq 3.0$ or $\geq 3.25$ ). Thinner cows at dry off tended $(P<0.14)$ to have increased yields of milk, fat, and true protein during the first 5 mo of the subsequent lactation (Table 7). Interestingly, we detected a trend $(P<0.11)$ for an interaction of prepartum BCS and nutritional grouping strategy for milk yield such that thinner cows fed treatment $\mathrm{S}$ produced the most milk, fatter cows

Table 7. Effects of BCS at dry off on milk yield and composition during the first 5 mo of the subsequent lactation.

\begin{tabular}{lcclll}
\hline & \multicolumn{2}{c}{ BCS } & & \\
\cline { 2 - 3 } Item & $\leq 3.0$ & $\geq 3.25$ & & SEM & $P$ \\
\hline Milk, kg/d & 42.9 & 41.2 & 0.9 & 0.12 \\
Fat, \% & 3.60 & 3.62 & 0.05 & 0.82 \\
Fat, kg/d & 1.55 & 1.48 & 0.03 & 0.14 \\
$3.5 \%$ FCM, kg/d & 43.3 & 42.1 & 0.9 & 0.29 \\
True protein, \% & 2.79 & 2.81 & 0.02 & 0.50 \\
True protein, kg/d & 1.20 & 1.15 & 0.02 & 0.14 \\
\hline
\end{tabular}

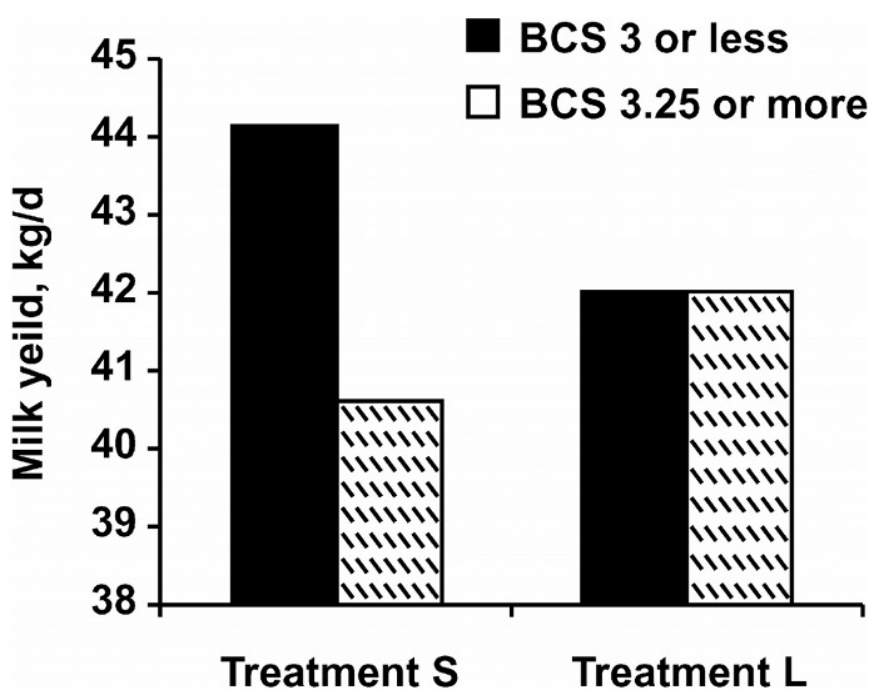

Figure 2. Milk yield during the first 5 mo of lactation as affected by BCS at dry off and nutritional grouping strategy during the dry period $(\mathrm{BCS} \times$ treatment, $P<0.11 ; \mathrm{SEM}=1)$.

fed treatment S produced the least milk, and cows of any BCS fed treatment produced an intermediate amount of milk during the first 5 mo of the subsequent lactation (Figure 2). Body condition score dynamics for cows as affected by treatment and BCS at dry off are presented in Figure 3. A 3-way interaction of BCS, treatment, and month existed $(P<0.01)$ such that fatter cows did not change BCS during the dry period, regardless of prepartum nutritional strategy. Thinner cows gained BCS during the dry period; the gain was greater if cows were fed treatment L. Regardless of initial BCS or prepartum treatment, BCS of the different groups were similar during mo 2 through 5 of lactation. In other experiments cows fed a close up diet for $3 \mathrm{wk}$ lost

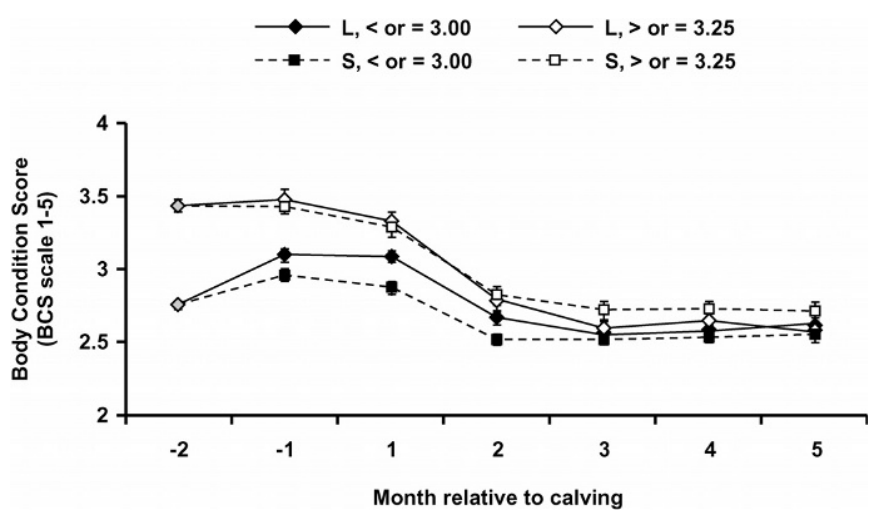

Figure 3. Effects of BCS at dry off and nutritional grouping strategy during the dry period on body condition dynamics during the transition period and early lactation $(\mathrm{BCS} \times$ treatment $\times$ month, $P$ $<0.01)$. 
Table 8. Effects of BCS at dry off on incidence of metabolic and nonmetabolic health disorders during the subsequent transition period.

\begin{tabular}{llr}
\hline & \multicolumn{2}{c}{ BCS } \\
\cline { 2 - 3 } Item & $\leq 3.0(\mathrm{n}=182)$ & $\geq 3.25(\mathrm{n}=110)$ \\
\hline Ketosis & $1.6 \%(3)$ & $2.7 \%(3)$ \\
Metritis & $1.1 \%(2)$ & $0.0 \%(0)$ \\
Retained fetal membranes & $9.3 \%(17)$ & $18.2 \%(20)$ \\
Displaced abomasums & $2.2 \%(4)$ & $1.8 \%(2)$ \\
Milk fever & $2.7 \%(5)$ & $4.5 \%(5)$ \\
Mastitis & $5.5 \%(10)$ & $5.5 \%(6)$ \\
Pneumonia & $3.3 \%(6)$ & $0.9 \%(1)$ \\
\hline
\end{tabular}

more BCS during the first 3 wk postpartum than cows fed the close up greater than 3 wk (Mashek and Beede, 2001). Although group DMI data were not available, we would hypothesize based upon these data that thinner cows consumed substantially more DM during the dry period and early lactation; fatter cows assigned to treatment L during the dry period must have had lower DMI during the dry period to avoid gaining BCS during the dry period. Consistent with this speculation, Hayirli et al. (2002) reported recently that DMI of cows during the close-up period decreased linearly with increasing BCS.

Effects of BCS at dry off on occurrence of most health disorders were minimal (Table 8). Fatter cows had increased $(P<0.05)$ incidence of retained fetal membranes. Reproductive performance was similar among cows of differing BCS at dry off (Table 9); however, a greater proportion of fatter cows were not pregnant by 250 DIM. Mashek and Beede (2001) reported a higher incidence of metritis and longer interval to first service for cows fed the close up diet for greater than $3 \mathrm{wk}$.

Pedron et al. (1993) determined that cows of higher BCS at calving lost more BCS and produced more milk during early lactation. Data from studies conducted with limited replication indicate increased DMI and milk yield by cows of lower BCS ( 2 to 2.5 versus 3.5 to 4 on a 4-point scale) at calving (Garnsworthy and Topps, 1982a, 1982b; Treacher et al., 1986; Garnsworthy and Jones, 1987). Our data are also consistent with those of Domecq et al. (1997), who reported that as BCS of

Table 9. Effects of BCS at dry off on subsequent reproductive performance through 250 DIM.

\begin{tabular}{lcclll}
\hline & \multicolumn{2}{c}{ BCS } & & \\
\cline { 2 - 3 } Item & $\leq 3.0$ & $\geq 3.25$ & & SEM & $P$ \\
\hline Days to first service & 66.7 & 66.4 & 1.8 & 0.89 \\
Days open & 115 & 107 & 8 & 0.40 \\
Services/conception & 2.3 & 2.2 & 0.2 & 0.60 \\
Cows not pregnant $^{1}$ & $32 / 176$ & $33 / 105$ & & \\
\hline
\end{tabular}

${ }^{1}$ Represents cows that left the herds or were otherwise not pregnant by 250 DIM. cows at dry off increased, milk yield during the first 120 DIM decreased; furthermore, thinner cows that gained BCS during the dry period yielded more milk during the first 120 DIM. Overall, in the context of modern transition cow management systems, cows of moderately lower BCS at dry off do not appear to have impaired milk production or poorer reproductive performance during the early lactation. However, further research should be conducted to explore the interactions of BCS and nutritional management of transition cows.

\section{CONCLUSIONS}

Overall, these data provide support to the 2-group system for nutritional management of dry cows. Cows of moderately lower BCS at dry off (2.75 to 3.0) appear to outperform cows of greater BCS at dry off, provided that modern nutritional management systems for transition cows are in place on commercial dairy farms.

\section{ACKNOWLEDGMENTS}

The authors gratefully acknowledge the assistance of Ramona Ehrhard for her assistance with laboratory analysis. We would also like to thank Drs. Alan Bell and Larry Chase for their input. Special thanks go to the herdspersons at True Farms and Noblehurst Farms and Jeff True and John Noble for their participation and cooperation in this research effort.

\section{REFERENCES}

Bell, A. W. 1995. Regulation of organic nutrient metabolism during transition from late pregnancy to early lactation. J. Anim. Sci. 73:2804-2819.

Campbell, I. L., and D. S. Flux. 1948. The relationship between level of nutrition during the dry period and subsequent production of dairy cattle. Page 61 in Proc. 8th Ann. Conf., New Zealand Soc. Animal Production.

Corbett, R. B. 2002. Influence of days fed a close-up dry cow ration and heat stress on subsequent milk production in western dairy herds. J. Dairy Sci. 85(Suppl. 1):191-192. (Abstr.)

Curtis, C. R., H. N. Erb, C. J. Sniffen, R. D. Smith, and D. S. Kronfeld. 1985. Path analysis of dry period nutrition, postpartum metabolic and reproductive disorders, and mastitis in Holstein cows. J. Dairy Sci. 68:2347-2360.

Dann, H. M., G. A. Varga, and D. E. Putnam. 1999. Improving energy supply to late gestation and early postpartum dairy cows. J. Dairy Sci. 82:1765-1778.

Domecq, J. J., A. L. Skidmore, J. W. Lloyd, and J. B. Kaneene. 1997. Relationship between body condition scores and milk yield in a large dairy herd of high yielding Holstein cows. J. Dairy Sci. 80:101-112.

Drackley, J. K. 1999. Biology of dairy cows during the transition period: The final frontier? J. Dairy Sci. 82:2259-2273.

Ferguson, J. D. 2001. Nutrition and reproduction in dairy herds. Pages 65-82 in Proc. 2001 Intermountain Nutr. Conf., Salt Lake City, UT. Utah State Univ., Logan.

Fox, D. G., C. J. Sniffen, J. D. O'Connor, J. B. Russell, and P. J. Van Soest. 1992. A net carbohydrate and protein system for evaluating cattle diets: III. Cattle requirements and diet adequacy. J. Anim. Sci. 70:3578-3596. 
Garnsworthy, P. C., and G. P. Jones. 1987. The influence of body condition at calving and dietary protein supply on voluntary food intake and performance in dairy cows. Anim. Prod. 44:347-353.

Garnsworthy, P. C., and J. H. Topps. 1982a. The effect of body condition of dairy cows at calving on their food intake and performance when given complete diets. Anim. Prod. 35:113-119.

Garnsworthy, P. C., and J. H. Topps. 1982b. The effects of body condition at calving, food intake, and performance in early lactation on blood composition of dairy cows given complete diets. Anim. Prod. 35:121-125.

Grummer, R. R. 1995. Impact in changes in organic nutrient metabolism on feeding the transition cow. J. Anim. Sci. 73:2820-2833.

Godden, S., J. Fetrow, P. Rapnicki, S. Eicker, and S. Stewart. 2002. Culling patterns in lactation. Proceedings Monsanto Dairy Business Science Symposium CD-ROM. St. Louis, MO.

Hayirli, A., R. R. Grummer, E. V. Nordheim, and P. M. Crump. 2002. Animal and dietary factors affecting feed intake during the prefresh transition period in Holsteins. J. Dairy Sci. 85:34303443.

Lees, F. T., C. P. McMeekan, and L. R. Wallace. 1948. The relationship between level of nutrition during the dry period and subsequent production of dairy cattle. Page 60 in Proc. 8th Ann. Conf., New Zealand Soc. Animal Production.

Mashek, D. G., and D. K. Beede. 2001. Peripartum responses of dairy cows fed energy-dense diets for 3 or 6 weeks prepartum. J. Dairy Sci. 84:115-125.

McCutcheon, S. N., and D. E. Bauman. 1986. Effect of chronic growth hormone treatment on responses to epinephrine and thyrotropinreleasing hormone in lactating cows. J. Dairy Sci. 69:44-51.

Minor, D. J., S. L. Trower, B. D. Strang, R. D. Shaver, and R. R. Grummer. 1998. Effect of nonfiber carbohydrate and niacin on periparturient metabolic status and lactation of dairy cows. J. Dairy Sci. 81:189-200.

Overton, T. R., M. S. Piepenbrink, and M. R. Waldron. 2000. Interactions of liver metabolism and health in transition dairy cows. Pages 251-261 in Proc. Cornell Nutr. Conf. Feed Manuf., Rochester, NY.

Pedron, O., F. Cheli, E. Senatore, D. Baroli, and R. Rizzi. 1993. Effect of body condition score at calving on performance, some blood parameters, and milk fatty acid composition in dairy cows. J. Dairy Sci. 76:2528-2535.

Robinson, P. H., J. M. Moorby, M. Arana, R. Hinders, T. Graham, L. Castelanelli, and N. Barney. 2001. Influence of close-up dry period protein supplementation on productive and reproductive performance of Holstein cows in their subsequent lactation. J. Dairy Sci. 84:2273-2283.

Schmidt, G. H., and L. H. Schultz. 1959. Effect of three levels of grain feeding during the dry period on the incidence of ketosis, severity of udder edema, and subsequent milk production of dairy cows. J. Dairy Sci. 42:170-179.

Treacher, R. J., I. M. Reid, and C. J. Roberts. 1986. Effect of body condition at calving on the health and performance of dairy cows. Anim. Prod. 43:1-6.

VandeHaar, M. J., G. Yousif, B. K. Sharma, T. H. Herdt, R. S. Emery, M. S. Allen, and J. S. Liesman. 1999. Effect of energy and protein density of prepartum diets on fat and protein metabolism of dairy cattle in the periparturient period. J. Dairy Sci. 82:1282-1295.

Woodward, T. E., J. B. Shepard, and R. R. Graves. 1932. Feeding management investigations at the United States dairy experiment station at Beltsville, MD. 1930 Report. USDA, Misc. Publ. 130(a). 